\title{
Dual Effect of Neutrophils on pIgR/Secretory Component in Human Bronchial Epithelial Cells: Role of TGF- $\beta$
}

\author{
Céline Ratajczak, Amélie Guisset, Bruno Detry, Yves Sibille, and Charles Pilette \\ Institute of Experimental and Clinical Research, Pole Pneumology, ENT and Dermatology, Cliniques Universitaires St-Luc, \\ Université Catholique de Louvain (UCL), Brussels B-1200, Belgium \\ Correspondence should be addressed to Charles Pilette, charles.pilette@uclouvain.be
}

Received 2 December 2009; Revised 17 May 2010; Accepted 24 May 2010

Academic Editor: Susan A. Rotenberg

Copyright ( $\odot 2010$ Céline Ratajczak et al. This is an open access article distributed under the Creative Commons Attribution License, which permits unrestricted use, distribution, and reproduction in any medium, provided the original work is properly cited.

Neutrophils have a dual affect on epithelial pIgR/SC, the critical receptor for transcellular routing of mucosal IgA, but mechanisms of $\mathrm{pIgR/SC}$ upregulation remain elusive. Requirements of cytokine, redox, and signalling pathways for pIgR/SC production were assessed in human bronchial epithelial (Calu-3) cells cocultured with increasing numbers of blood neutrophils. Increased SC production was observed after incubation for $48 \mathrm{hrs}$ with intermediate neutrophil numbers $\left(1.25\right.$ to $\left.2.5 \times 10^{6}\right)$, was favoured by the elastase inhibitor SLPI, and correlated with increased TGF- $\beta$ production. Exogenous TGF- $\beta$ stimulated SC production with a maximal effect at $48 \mathrm{hrs}$ and both TGF- $\beta$ - and neutrophil-driven SC upregulation were dependent on redox balance and p38 MAP-kinase activation. This paper shows that activated neutrophils could upregulate epithelial pIgR/SC production through TGF- $\beta$-mediated activation of a redox-sensitive and p38 MAPK-dependent pathway. An imbalance between the two neutrophildriven opposite mechanisms (SC upregulation and SC degradation) could lead to downregulation of pIgR/SC, as observed in severe COPD.

\section{Introduction}

The mucosal surfaces lining the respiratory tract are continuously exposed to potentially infectious agents, as well as environmental toxics and antigens. The bronchial epithelium acts as a physicochemical barrier of the airway mucosa and is able to initiate inflammatory responses by releasing mediators upon exposure to stimuli such as cigarette smokeor pathogen-derived molecules. One first-line mechanism of the airway immune defense against inhaled antigens and microorganisms consists of secretory immunoglobulin A (SIgA), the predominant immunoglobulin isotype in mucosal secretions $[1,2]$. In the lamina propria, mucosal plasma cells produce IgA molecules mainly as polymers, linked through a joining chain. Polymeric IgA (pIgA) then binds to the polymeric Ig receptor (pIgR), a transmembrane glycoprotein selectively expressed on the basolateral surface of epithelial cells. The pIgA-pIgR complexes are transported across epithelial cells up to the apical membrane where a proteolytic cleavage releases the main part of the extracellular domain of pIgR, known as secretory component (SC), remaining bound to pIgA to form SIgA [3] which assumes protective, antiinfectious functions within the mucosal lumen.

Chronic obstructive pulmonary disease (COPD) represents the fourth leading cause of death worldwide and results in large consumption of health care resources [4]. This disorder characterized by progressive and mostly irreversible limitation of expiratory airflow [5] is mainly caused by cigarette smoking, whereas only some (1520\%) smokers will develop the disease. Among features of COPD are epithelial changes (mucous hyperplasia) and chronic inflammation with recruitment/activation of leukocytes including neutrophils, macrophages, and $\mathrm{CD}^{+}$ $\mathrm{T}$ cells [6]. However, the links between airway neutrophilic inflammation and impairment of epithelial functions remain poorly understood in COPD. We previously showed that expression of $\mathrm{pIgR} / \mathrm{SC}$ was strongly decreased in the bronchial epithelium from patients with severe COPD, and that this epithelial defect correlated with airflow limitation and with infiltration of submucosal glands by neutrophils [7]. 
Neutrophils can be involved in various lung disorders notably through the release of oxidants, proteinases (including serine proteinases) and defensins, which have important effects on several epithelial functions such as mucus secretion, cytokine release, or receptor expression. More specifically, we next showed that activated neutrophils can induce in vitro a cleavage of epithelial $\mathrm{pIgR} / \mathrm{SC}$ through the release of serine proteinases (particularly neutrophil elastase), whereas a stimulatory effect on $\mathrm{pIgR} / \mathrm{SC}$ production by cultured bronchial epithelial cells was also observed [8]. However, the mechanisms regulating this opposite effect of neutrophils on $\mathrm{pIgR} / \mathrm{SC}$ expression in airway epithelial cells remain unclear, in particular factors responsible for increased pIgR/SC synthesis upon stimulation by neutrophils are not identified.

The aim of the present work was therefore to evaluate the molecular determinants of the "dual effect" of neutrophils on $\mathrm{pIgR} / \mathrm{SC}$ expression in human bronchial epithelial cells. More particularly, the involvement of soluble mediators in the epithelial $\mathrm{pIgR} / \mathrm{SC}$ upregulation by neutrophils was investigated, as well as the role of proteinase/antiproteinase and redox balances and of intracellular MAPKinase signaling pathways.

\section{Materials and Methods}

2.1. Cell Cultures. Calu-3, a human (adenocarcinoma) bronchial epithelial cell line, was obtained from the ATCC (Rockville, MD), and cultured in RPMI-1640 supplemented with $10 \%$ decomplemented fetal bovine serum, $100 \mathrm{IU} / \mathrm{ml}$ penicillin, $100 \mu \mathrm{g} / \mathrm{ml}$ streptomycin and $2 \mathrm{mM} \mathrm{L}$-glutamine (Cambrex, Rockland, ME) and referred to as "complete medium". 96-well plates were precoated for $2 \mathrm{hrs}$ at $37^{\circ} \mathrm{C}$, with $3.1 \mu \mathrm{g} / \mathrm{ml}$ vitrogen (Cohesion, Palo Alto, CA), $10 \mu \mathrm{g} / \mathrm{ml}$ fibronectin, and $50 \mu \mathrm{g} / \mathrm{ml}$ bovine serum albumin in RPMI and followed by two washes with RPMI. To obtain a confluent bronchial epithelial layer, 50,000 Calu-3 cells were seeded in this 96 -well plate in $200 \mu$ l of complete medium and cultured for 5-7 days until confluence.

Polymorphonuclear neutrophils were obtained from whole heparinized blood from healthy donors by a one-step density gradient method (40 min centrifugation, $800 \times \mathrm{g}$, room temperature) using Polymorphprep (Axis Shield, Oslo, Norway) following manufacturer's protocol. After washing, neutrophils were resuspended in RPMI-1640 and activated by $20 \mathrm{ng} / \mathrm{ml}$ IL-8 (R\&D System, Minneapolis, MN) for $5 \mathrm{~min}$ followed by $1 \mathrm{nM}$ formyl-Methionyl-Leucyl-Phenylalanine (fMLP) (Sigma Aldrich, Saint Louis, MO) for $30 \mathrm{~min}$ at $37^{\circ} \mathrm{C}$ [8]. In all experiments, IL-8/fMLP activated neutrophils were represented by "activated neutrophils".

2.2. Cell Stimulation. Activated neutrophils alone were incubated (from 1.25 to $5 \times 10^{6}$ cells) in complete medium for $48 \mathrm{hrs}$ to determine the production of cytokines including TGF- $\beta 1$ in supernatants.

Confluent Calu-3 bronchial epithelial cells were cultured for $48 \mathrm{hrs}$, with or without TGF- $\beta 1(20 \mathrm{ng} / \mathrm{ml}, \mathrm{R} \& \mathrm{D}$ System). To evaluate the dose response to TGF- $\beta 1$, cells were incubated with increasing concentration from 0.2 to $80 \mathrm{ng} / \mathrm{ml}$. After culture, pIgR/SC production was measured in supernatants and cell lysates.

Calu-3/neutrophils coculture. To analyse the doseresponse effect of neutrophils on SC production by bronchial epithelial cells, confluent monolayers of Calu-3 cells were incubated for $48 \mathrm{hrs}$ with increasing numbers of activated neutrophils (from 0.3 to $15 \times 10^{6}$ cells) in the presence or not of $2.5 \mu \mathrm{M}$ human Secretory Leukocyte Protease Inhibitor (SLPI, R\&D system).

Kinetics (from 2 to $72 \mathrm{hrs)} \mathrm{of} \mathrm{TGF-} \beta 1$ production by Calu-3 epithelial monolayers alone, activated neutrophils $\left(5 \times 10^{6}\right.$ cells $)$ alone or bronchial epithelial cells cocultured with neutrophils was also analyzed. Similarly, kinetics (from 1 to $48 \mathrm{hrs}$ ) of SC secretion by Calu-3 epithelial layers was measured after incubation with TGF- $\beta-1(20 \mathrm{ng} / \mathrm{ml})$ or activated neutrophils $\left(5 \times 10^{6}\right.$ cells $)$.

At the end of each culture, the required volume of supernatant was taken to measure elastase enzymatic activity, and $2 \mathrm{mM}$ Phenylmethylsulfonyl fluoride (PMSF, Sigma Aldrich) was then added to inhibit further serine proteinase activity. Supernatants were harvested and frozen at $-20^{\circ} \mathrm{C}$ until SC titration. Epithelial cells were washed twice in PBS and lysed with $100 \mu \mathrm{l}$ Triton (Sigma Aldrich) $0.1 \% \mathrm{w} / \mathrm{v}$ in PBS for $15 \mathrm{~min}$ on ice. Cell lysates were harvested and frozen at $-20^{\circ} \mathrm{C}$ until SC titration.

Independent experiments represent results from different neutrophil donors.

2.3. Cytotoxicity Assay. Cell viability and activity of mitochondrial electron transport chain, as indicator for cytotoxicity, was determined by the capacity of cells to reduce MTT (3-(4,5-dimethylthiazol-2-yl)-2,5-diphenyltetrazolium bromide) to formazan [9]. Confluent Calu-3 epithelial cells were incubated with increasing number of neutrophils (from 0.3 to $15 \times 10^{6}$ ), with increasing concentrations of TGF- $\beta$ (from 0.2 to $80 \mathrm{ng} / \mathrm{ml}$ ), with CSE (from $0.1 \%$ to $10 \%$ ) and with MAPKinases inhibitors (PD, SP, and SB) for $48 \mathrm{hrs}$. After incubation, cells were washed with PBS. $100 \mu \mathrm{l}$ of PBS containing $1 \mathrm{mg} / \mathrm{ml}$ MTT was added to each well and the plate was returned to $37^{\circ} \mathrm{C}$. After $1 \mathrm{~h}$, the medium was removed by flicking off. To solubilize intracellular formazan produced by active mitochondria in living cells, $100 \mu \mathrm{l}$ of dimethylsulfoxide (DMSO) was added per well. The absorbance at $550 \mathrm{~nm}$ was measured on a spectrophotometric plate reader and used for the calculation of relative cell viability where untreated cells represented $100 \%$ viability.

2.4. ELISA for Human SC and TGF- $\beta 1$. SC concentration was determined in culture supernatants and cell lysates from epithelial cells by sandwich ELISA, as previously reported [8], by using affinity purified goat antihuman SC polyclonal antibody (developed in our laboratory, recognizing both soluble SC and membrane pIgR/SC) as capture and detection (biotinylated) antibody. The reaction was revealed by streptavidine-HRP followed by tetramethylbenzidine (TMB) in the presence of hydrogen peroxide. OD were recorded at 
$450 \mathrm{~nm}$ using a microplate spectrometer (Biorad). Sensitivity of the immunoassay was $\sim 0.2 \mathrm{ng} / \mathrm{ml}$.

TGF- $\beta$ production was measured in supernatants from Calu-3 cells, neutrophils or Calu-3/neutrophils cocultures by ELISA. A step of sample extraction (acidification) was carried out to allow for the release of TGF- $\beta 1$ from latent complexes, making it accessible for measurement in the immunoassay. A monoclonal antibody specific for TGF- $\beta 1$ had been coated onto the wells and extracted samples and standards were put into these wells followed by addition of biotinylated secondary antibody (TGF- $\beta$ immunoassay kit, Biosource, Nivelles, Belgium). The sensitivity of TGF- $\beta 1$ immunoassay was $15.6 \mathrm{pg} / \mathrm{ml}$.

\subsection{Determination of Neutrophil Elastase Activity.} Neutrophil elastase activity was measured in epithelial cell/neutrophils coculture supernatants. N-methoxysuccinylala-ala-pro-val-p-nitroanilide (Sigma Chemical) was used as specific substrate, diluted at $1 \mathrm{mM}$ in $0.1 \mathrm{M}$ HEPES buffer, $\mathrm{pH} 7.5$, with $0.5 \mathrm{M} \mathrm{NaCl}$ and $10 \% \mathrm{v} / \mathrm{v}$ dimethylsulfoxide. Supernatants $(50 \mu \mathrm{l})$ were incubated with $100 \mu \mathrm{l}$ of substrate solution at $37^{\circ} \mathrm{C}$ in 96-well plates, and $\mathrm{OD}$ increase was monitored at $415 \mathrm{~nm}$ using a microplate reader (Biorad). Results were compared with standard curves obtained with serial dilutions of purified neutrophil elastase (Elastin products Co., Owensville, MA), and expressed in nmole/l.

2.6. Analysis of Redox Changes. Confluent bronchial epithelial layers were incubated for $48 \mathrm{hrs}$ with TGF- $\beta 1(20 \mathrm{ng} / \mathrm{ml})$ or with PMN $\left(5 \times 10^{6}\right)$ in the presence of the antioxidants $\mathrm{N}$-acetylcystein or glutathione (Sigma) at final concentration of $10 \mathrm{mM}$. The production of SC was measured in supernatants.

2.7. Western Blot Analysis of MAPKinases. After $30 \mathrm{~min}$ of stimulation by TGF- $\beta$ of a confluent monolayer in a 12-well plate, Calu-3 cells were lyzed in $150 \mu \mathrm{l}$ of RIPA buffer $[16 \mathrm{mM}$ Tris base, $150 \mathrm{mM} \mathrm{NaCl}, 6 \mathrm{mM}$ EDTA, $10 \mathrm{~g}$ Nonidet (NP-40), $12 \mathrm{mM}$ sodium deoxycholate, $3 \mathrm{mM}$ SDS, and $\mathrm{pH}$ 7.4] with $10 \mu \mathrm{g} / \mathrm{ml}$ of protease cocktail inhibitor (Roche), $1 \mathrm{mM}$ PMSF, $1 \mathrm{mM} \mathrm{NaF}$ and $1 \mathrm{mM} \mathrm{Na} 3 \mathrm{VO} 4.40 \mu \mathrm{l}$ of protein lysate are diluted in $40 \mu \mathrm{l}$ of Laemmli's sample buffer, heated at $100^{\circ} \mathrm{C}$ for $5 \mathrm{~min}$, loaded in a $12 \%$ SDS-PAGE gel and run at $180 \mathrm{~V}$ for $1 \mathrm{~h}$. Cell proteins were transferred onto a nitrocellulose membrane (Hybond-C, Amersham Biosciences, UK) at $70 \mathrm{~mA}$ for $1.5 \mathrm{~h}$ at room temperature. The membrane was blocked with 5\% BSA in Tris-buffered saline with $0.1 \%$ Tween 20 (TBST) for $1 \mathrm{~h}$ at room temperature, washed, and incubated with the primary Ab diluted 1/1000 in TBST-BSA 1\% (anti-phospho ERK, anti-phospho p38 or anti-phospho JNK; Cell signalling Technology, Beverly, MA) overnight at $4^{\circ} \mathrm{C}$. Membranes were then incubated for $1 \mathrm{~h}$ at room temperature with a secondary Ab diluted 1/2000 in TBSTBSA 1\% (anti-rabbit IgG/HRP, Cell signalling Technology). Immunoreactive bands were developed using chemiluminescence (ECL, Amersham Biosciences, UK) and detected with the Chemidoc XRS apparatus (Bio-Rad Laboratories, Hercules, CA).
2.8. MAP Kinase Inhibition Assay. Calu-3 epithelial cells were pretreated for $1 \mathrm{hr}$ with $50 \mu \mathrm{M}$ PD98059, $50 \mu \mathrm{M}$ SB203580 or $50 \mu \mathrm{M}$ SP600125 as selective inhibitors of extracellular signal-regulated kinase-1/2 (ERK) mitogen-activated protein kinase (MAPK), p38 MAPK, and c-jun-N-Terminal Kinase (JNK) MAPK, respectively (New England Biolabs, Beverly, MA). Calu-3 cells were then incubated for $48 \mathrm{hrs}$ with TGF$\beta 1(20 \mathrm{ng} / \mathrm{ml})$ or neutrophils $\left(5 \times 10^{6}\right.$ cells $)$, and production of SC in supernatants was determined by ELISA.

2.9. Statistical Analysis. Results were expressed as mean \pm SEM, unless otherwise stated. The differences between the groups were analyzed as appropriate by means of the Mann Whitney test, using Graphpad Prism 4.0 (Graphpad Prism, San Diego, CA). $P$ values $<.05$ were considered as statistically significant.

\section{Results}

3.1. Neutrophils Have a Dual Effect on pIgR/SC Production. To set up a model to examine effects of neutrophils on SC production by bronchial epithelial cells, confluent epithelial layers of Calu-3 cells were incubated for $48 \mathrm{hrs}$ with increasing numbers of activated neutrophils (Figure 1(a)), with evaluation of cytotoxicity. Neutrophil concentrations from $0.3 \times 10^{6}$ to $5 \times 10^{6}$ did not significantly affect epithelial cell viability according to MTT assay (viability $\geq 80 \%$ compared to control). However cytotoxicity was observed for $\geq 10 \times 10^{6}$ neutrophils (cell viability decreased by $\sim 20 \%$ ).

SC production increased when epithelial cells were incubated with neutrophils, starting at $1.25 \times 10^{6}$ and with a maximal increase at $2.5 \times 10^{6}$ neutrophils $(P<$ .01 , Figure 1(a)). At further increased neutrophil numbers $\left(>5 \times 10^{6}\right)$, SC production was downregulated and tended to decrease at $15 \times 10^{6}$ neutrophils as compared to control $(P=$ .08 , Figure 1(a)), consistent with cytotoxicity (MTT assay) and/or proteolytic cleavage [8]. Elastase activity evaluated in supernatants from the same Calu-3/neutrophils cocultures increased as expected with the number of neutrophils (Figure 1(b)). These results indicated that this system allowed to address the two opposite effects of neutrophils on epithelial SC, and experiments were carried out to explore the mechanisms of SC upregulation by "nontoxic" numbers of neutrophils releasing elastase in a concentration range that could be observed in chronic airway neutrophilic diseases, for example, during exacerbations.

3.2. Neutrophil-Driven SC Upregulation Is Modulated by Serine Proteinase Activity. To evaluate the role of serine proteinases on the regulation of SC production by neutrophils, Calu-3 cells were cultured with increasing neutrophil numbers in the presence or not of secretory leukocyte protease inhibitor (SLPI), a natural inhibitor of neutrophil elastase, at a concentration $(2.5 \mu \mathrm{M})$ almost completely suppressing elastase activity ( $>90 \%$ inhibition). SC production was measured in both epithelial supernatants and cell lysates (Figure 2). In the presence of exogenous SLPI, SC upregulation observed in epithelial supernatants 


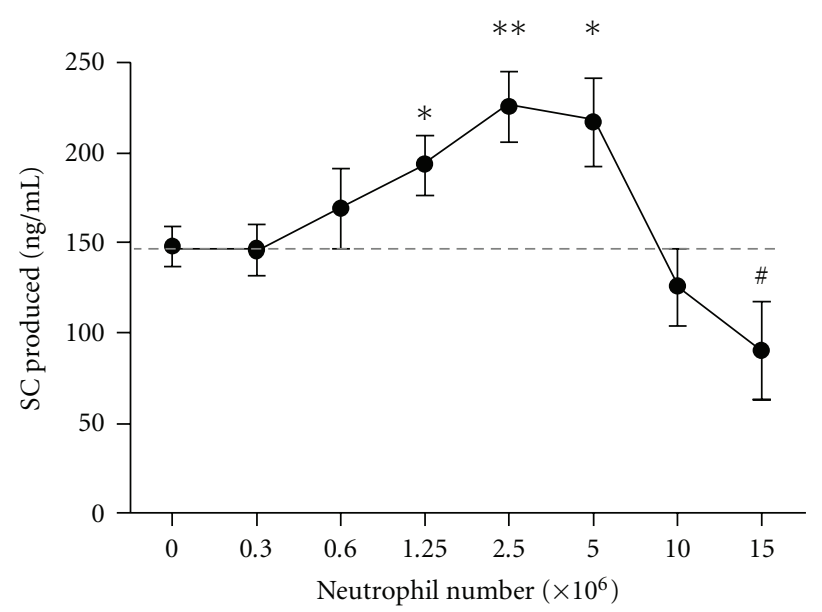

(a)

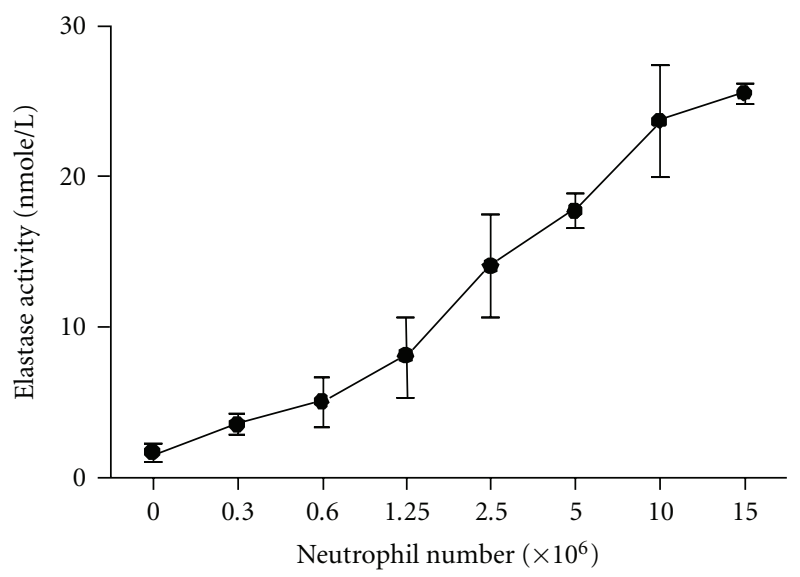

(b)

Figure 1: Dual effect of neutrophils on SC secretion. Confluent monolayers of Calu-3 cells were incubated in triplicates for 48 hrs with increasing numbers of neutrophils, from $0.3 \times 10^{6}$ to $15 \times 10^{6}$ cells. (a) SC concentration and (b) elastase activity were measured in supernatants, as described in Methods. Data are means \pm SEM $(n=6$ independent experiments $)$. ${ }^{*} P=.08,{ }^{*} P \leq .05$ and ${ }^{* *} P \leq .01$ as compared with control.

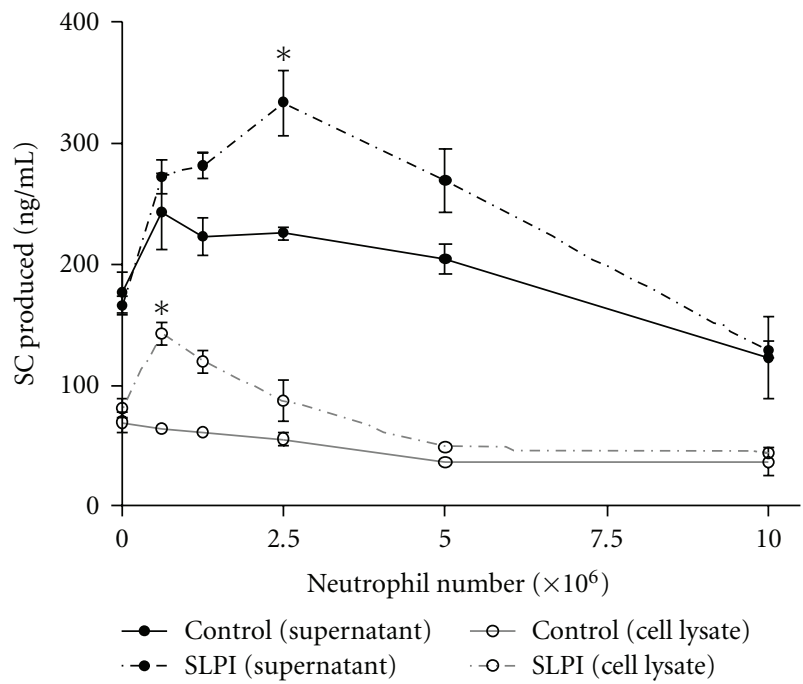

Figure 2: Effect of Secretory Leucoproteinase Inhibitor (SLPI) on pIgR/SC production. Confluent Calu-3 monolayers were cultured with increasing numbers of neutrophils $\left(0.6 \times 10^{6}\right.$ to $10 \times 10^{6}$ cells $)$ in the presence (dashed line) or in the absence (full line) of SLPI. After $48 \mathrm{hrs}$, SC production was measured in supernatants (black lines) and in cell lysates (grey lines). Data are means \pm SD of one experiment (out of 2 ) in triplicates. ${ }^{*} P \leq .05$ as compared with control.

at intermediate neutrophil numbers $\left(P<.05\right.$ at $2.5 \times 10^{6}$ neutrophils) was further increased. In addition, the presence of SLPI promoted an increase in pIgR/SC in epithelial lysates $\left(P<.05\right.$ at $0.6 \times 10^{6}$ neutrophils $)$, while no effect was observed in this cell compartment in the absence of SLPI (Figure 2) or with SLPI alone, without neutrophils (data not shown).
3.3. TGF- $\beta$ Is Increased upon Coculture of Calu-3 Cells with Neutrophils. Besides the effect of proteinases/antiproteinases on SC upregulation, involvement of other neutrophil (and/or epithelial)-derived soluble factors was assessed. Cytokines known to induce pIgR transcription such as TNF- $\alpha$ or IL- $1 \beta$ were not detected in coculture supernatants (data not shown). In contrast, TGF- $\beta$, which was detected in resting Calu-3 cell supernatants at a similar level as in complete (serum-supplemented) medium, was increased upon neutrophil coculture $\left(\sim 3\right.$-fold increase at $5 \times 10^{6}$ neutrophils, $P<.05$; Figure $3(\mathrm{a}))$.

In order to determine the respective role of epithelial cells and neutrophils in TGF- $\beta$ production, a time course of TGF$\beta$ production by epithelial cells alone, activated neutrophils alone or epithelial cell/neutrophil cocultures was carried out (Figure 3(b)). A trend for TGF- $\beta$ increase was observed in neutrophil and coculture supernatants as early as after $2 \mathrm{hrs,}$ and further increased at later time points $(P<.05$ at 48 and 72 hrs, Figure 3(b)) in cocultures. In contrast, epithelial cells began to secrete TGF- $\beta$ between $48-72$ hrs, with a 3 fold increase as compared to 2 hrs $(P<.05)$. At each time point, TGF- $\beta$ in neutrophil supernatants was higher than the epithelial production, except at $72 \mathrm{hrs}$. These results indicated that neutrophils represented the main source of TGF- $\beta$ up to 48 hrs of coculture, with a modest (and late) contribution from epithelial cells.

3.4. TGF- $\beta$ Upregulates Epithelial pIgR/SC Production. TGF$\beta$ was then evaluated for a potential effect on $\mathrm{pIgR/SC}$ production. TGF- $\beta$ had no significant cytotoxic effect on epithelial cell viability up to $80 \mathrm{ng} / \mathrm{ml}$, with even increased MTT reduction at $80 \mathrm{ng} / \mathrm{ml}$ (not shown). Addition of recombinant human TGF- $\beta 1$ significantly increased $\mathrm{pIgR} / \mathrm{SC}$ production, in cell lysates $(P<.05$; Figure $4(\mathrm{a}))$, and a trend was also observed for SC secretion in supernatants. 


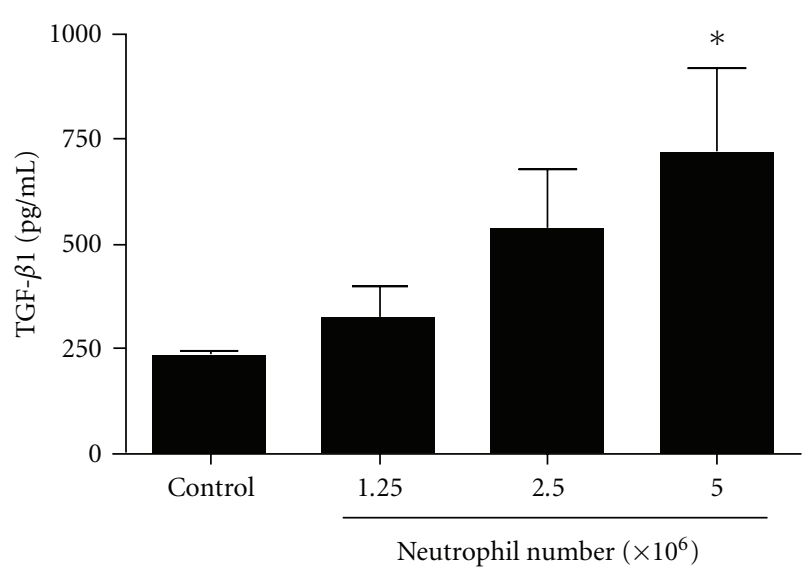

(a)

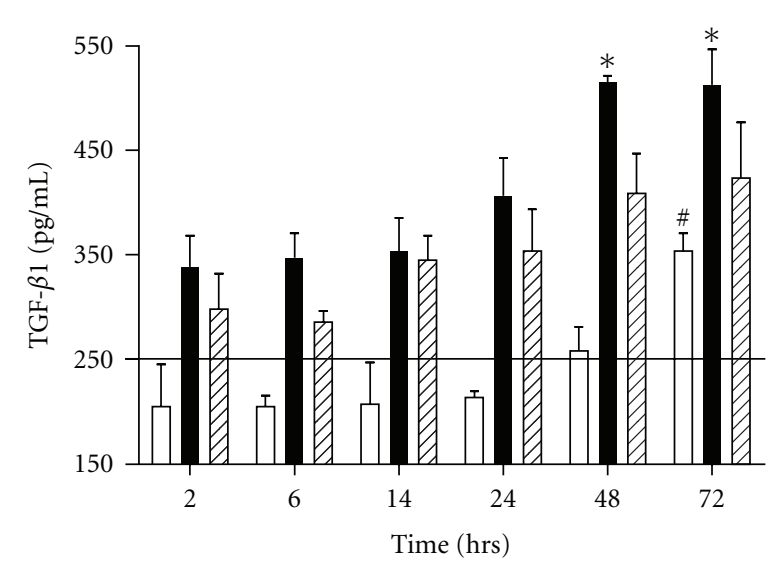

Calu-3

Calu-3 + neutrophils Neutrophils

FIGURE 3: TGF- $\beta 1$ production in epithelial/neutrophil cocultures. (a) TGF- $\beta 1$ production was measured by ELISA in supernatants of Calu-3 cells incubated for $48 \mathrm{hrs}$ with increasing numbers of neutrophils ( $1.25 \times 10^{6}$ to $5 \times 10^{6}$ cells). (b) Kinetics (from 2 to 72 hrs) of TGF$\beta 1$ production by Calu-3 cells alone (open bars), neutrophils alone $\left(5 \times 10^{6}\right.$ cells, stripped bars) or epithelial cell/neutrophil cocultures $\left(5 \times 10^{6}\right.$ neutrophils, solid bars). The horizontal bar represents TGF- $\beta 1$ concentration in complete medium, containing fetal calf serum $(201 \pm 40 \mathrm{pg} / \mathrm{ml}$, mean $\pm \mathrm{SD}, n=3)$. Data are means $\pm \operatorname{SEM}(n=4$ independent experiments, both for a and $\mathrm{b})$. (a) ${ }^{*} P \leq .05$ as compared with control; (b) ${ }^{*} P \leq .05$ as compared with Calu-3 alone, ${ }^{\#} P \leq .05$ as compared with Calu-3 at 2 hrs.

In dose-response experiments, SC production upon TGF$\beta$ stimulation increased from $1 \mathrm{ng} / \mathrm{ml}$ to reach a plateau $\sim 20 \mathrm{ng} / \mathrm{ml}$ (Figure 4(b)). The kinetics of SC production by bronchial epithelial cells incubated with TGF- $\beta$ or neutrophils, the main source of TGF- $\beta$, was assessed (Figure $4(\mathrm{c})$ ). From $1 \mathrm{hr}$ to $14 \mathrm{hrs}$ of incubation, no difference was observed between the three conditions of stimulation, constitutive SC production starting to significantly increase from 24 hrs. Effects of TGF- $\beta$ and neutrophils had similar kinetics on SC production, with upregulation observed at $48 \mathrm{hrs}$ (Figure 4(c)).

3.5. SC Upregulation by TGF- $\beta$ and Neutrophils Depends on the Redox Balance. We examined whether the redox balance could affect TGF- $\beta$ - and neutrophil-induced SC upregulation. Calu- 3 cells were cultured with TGF- $\beta$ or neutrophils in the presence or not of two antioxidants, $\mathrm{N}$-acetylcysteine and glutathione. In the presence of these antioxidants, effects of neutrophils were inhibited, with a trend for TGF$\beta$ (Figure 5(a)). N-acetylcysteine and glutathione had no effect on TGF- $\beta$ production, whereas they did slightly reduce elastase activity presumably by reducing the $\mathrm{pH}$ (data not shown).

The link between p38 MAPK activation and redox balance in epithelial cells cocultured with activated neutrophils was assessed. Activation of p38 and ERK was assayed in Calu3 cells cocultured with neutrophils in the presence or not of N-acetylcysteine (Figure 5(b)). Upon neutrophil coculture ERK was activated at $60 \mathrm{~min}$, while p 38 was activated as soon as after $5 \mathrm{~min}$ and also peaked at $60 \mathrm{~min}$. In the presence of the antioxidant, p38 MAPK activation was inhibited, whereas that of ERK was not affected or even promoted.
3.6. SC Upregulation by TGF- $\beta$ and Neutrophils Depends on p38 MAPK Activation. To analyse the intracellular mechanisms involved in SC upregulation and engaged in bronchial epithelial cells activated by TGF- $\beta$ or neutrophils, activation of ERK, p38, and JNK MAPKinase was assessed, as well as effects of their selective inhibition. For each inhibitor, specificity and absence of significant cytotoxicity was confirmed by western blot and MTT assay, respectively (data not shown). Activation of ERK and p38 MAPK was confirmed in Calu- 3 stimulated by TGF- $\beta$, with a maximal effect at 5 min both for ERK and p38 (Figure 6(a)).

The pharmacologic inhibitors did not significantly affect baseline SC secretion (Figure 6(b)). While no significant effects were observed with ERK or JNK pathway inhibitors (PD98059 and SP600125, resp.), the p38 MAPK inhibitor (SB203580) suppressed neutrophil- and TGF- $\beta$-driven SC upregulation $(P<.05$, Figure 6(b)).

\section{Discussion}

Epithelial pIgR/SC is the critical receptor for the transcellular routing of IgA involved in frontline defense mechanisms at mucosal surfaces, including the airways. We previously observed that the bronchial epithelium of severe COPD displays a strongly reduced pIgR/SC expression, which correlated with airway obstruction and neutrophil infiltration [7]. Our previous in vitro study showed that neutrophils could induce on one hand pIgR/SC cleavage and on the other hand upregulation of SC production in epithelial cells [8], suggesting a "dual effect" of neutrophils on pIgR/SC. This study shows that, in an in vitro coculture system set up to address the mechanisms of pIgR/SC dual regulation by 


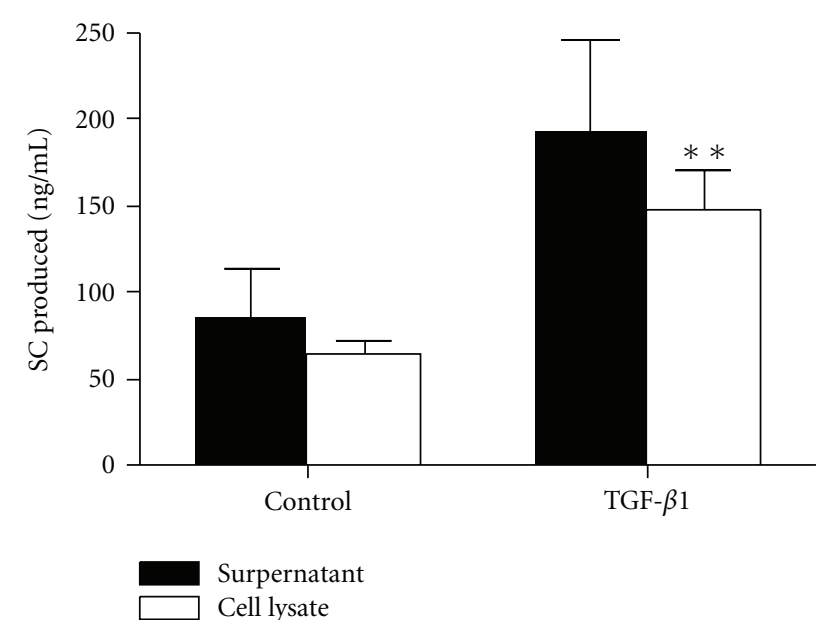

(a)

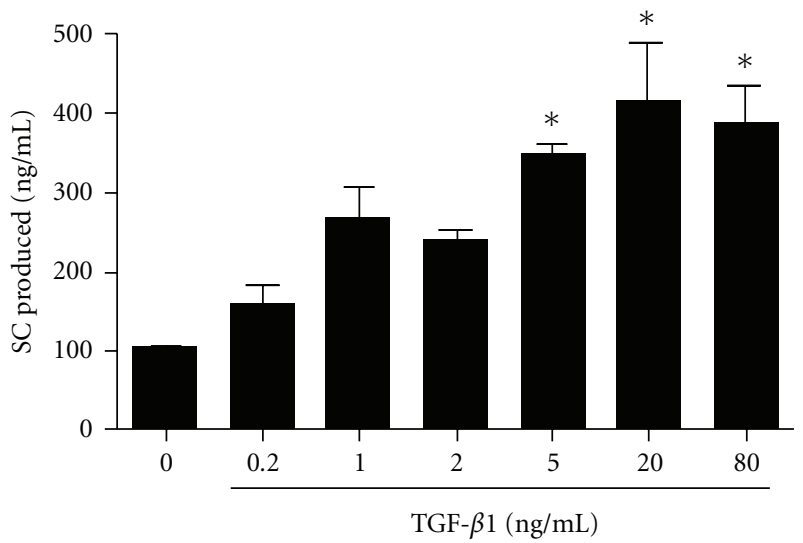

(b)

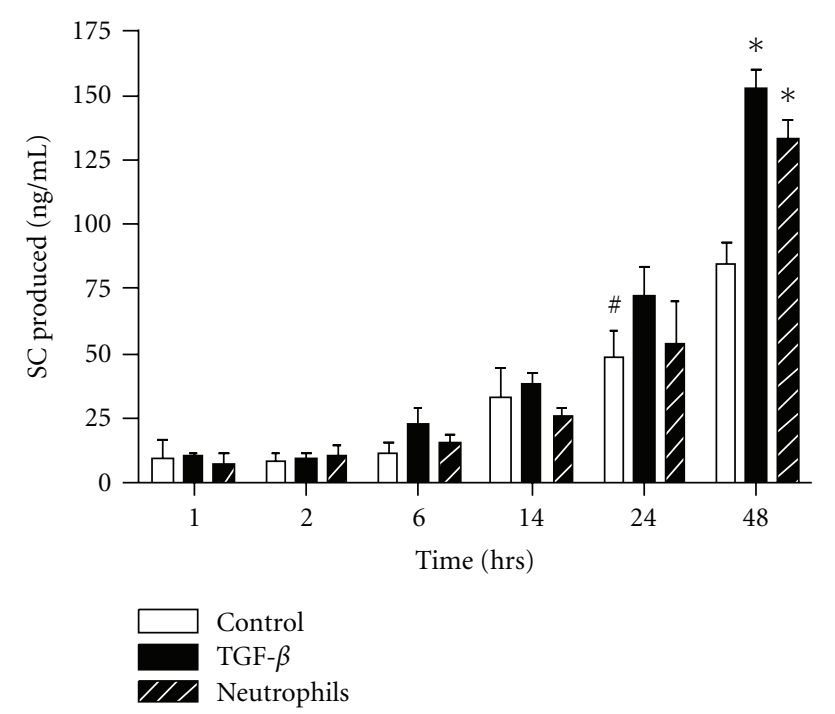

(c)

Figure 4: Effect of TGF- $\beta 1$ on pIgR/SC production. (a) Calu-3 cells were cultured for $48 \mathrm{hrs}$ with or without TGF- $\beta 1$ (20 ng/ml). SC production was evaluated in supernatants (solid bars) and in cell lysates (open bars). (b) Calu-3 cells were exposed to increasing concentration of TGF- $\beta 1(0.2$ to $80 \mathrm{ng} / \mathrm{ml})$ for $48 \mathrm{hrs}$, and SC was measured in supernatants. (c) SC production was assessed in supernatants from resting Calu-3 cells as control (open bars), Calu-3 cells incubated with TGF- $\beta 1$ ( $20 \mathrm{ng} / \mathrm{ml}$, solid bars) and Calu-3 cells/neutrophil cocultures (stripped bars) for $1 \mathrm{hr}$ to $48 \mathrm{hrs}$. Results are expressed as means \pm SEM for (a) ( $n=7$ independent experiments with triplicates), (b) $(n=3)$ and (c) $(n=3) .{ }^{*} P<.05$ as compared with control (a, b, c); ${ }^{*} P<.05$ as compared with control at $1 \mathrm{hr}$ (c).

neutrophils, increased epithelial SC production was observed at intermediate numbers of neutrophils (corresponding to $\sim 10 \mathrm{nM}$ elastase released), while further increasing neutrophils downregulated SC, presumably due to proteolytic cleavage (>20 nM elastase; [8]) and/or cytotoxic effects. In addition, SC upregulation was favoured in the presence of SLPI, a natural elastase inhibitor, and associated with TGF- $\beta$ production by neutrophils. Moreover, we show for the first time that TGF- $\beta$ is able to stimulate epithelial $\mathrm{pIgR} / \mathrm{SC}$ production, in a dose-dependent manner. We also demonstrate that TGF- $\beta$ - and neutrophil-driven SC upregulation depends on the redox balance (cigarette smoke extracts and antioxidants both suppressing the effect) and that p38 MAP kinase represents a downstream, intracellular signalling pathway targeted by TGF- $\beta$ to induce $\mathrm{pIgR} / \mathrm{SC}$ production upon stimulation by neutrophils.

Neutrophils are able to secrete a large range of soluble factors including proteinases and oxidants, as well as cytokines/chemokines and growth factors, involved in inflammatory responses and tissue remodelling. Among these factors produced by neutrophils, our data indicate that elastase and TGF- $\beta$ represent the major candidates to underlie, respectively, the down- and upregulation of $\mathrm{pIgR} / \mathrm{SC}$ in epithelial cells exposed to activated neutrophils. A robust production of TGF- $\beta$ was detected in our coculture supernatants, mainly arising from neutrophils. In addition, 


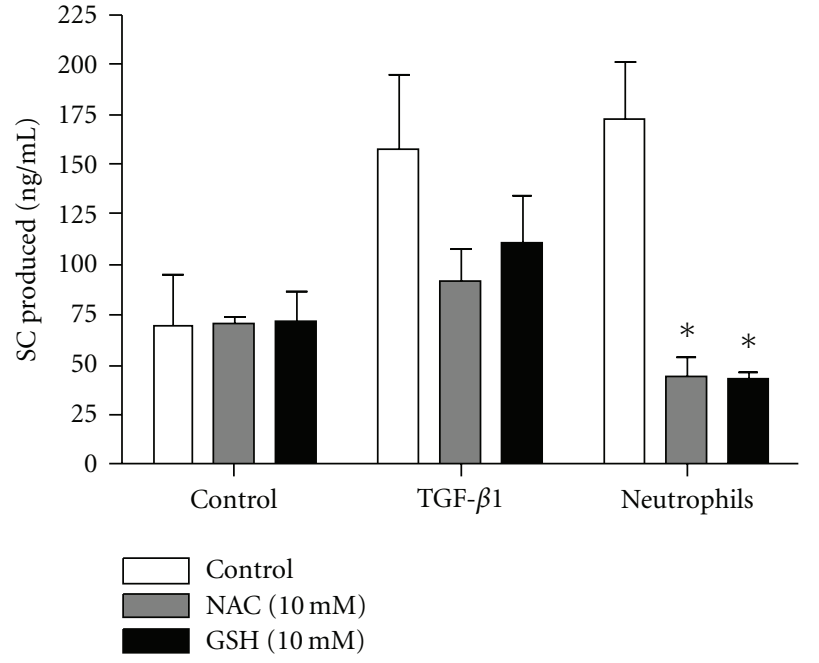

(a)

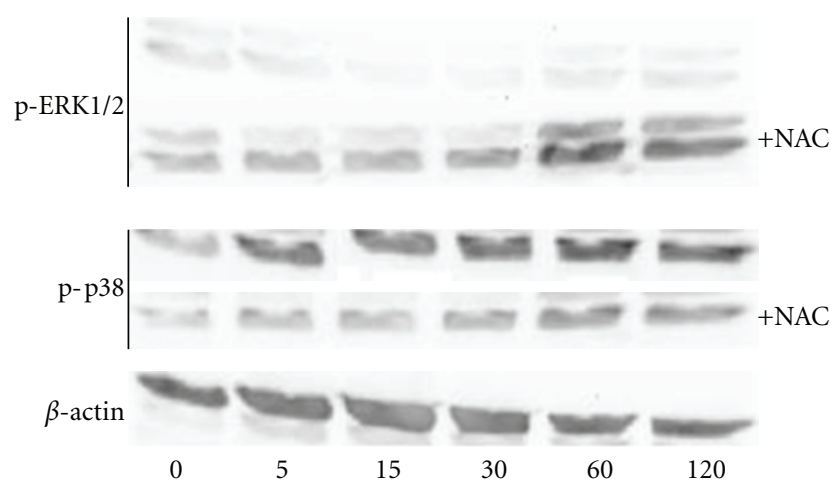

(b)

FIgURE 5: Effect of redox changes on TGF- $\beta$ and neutrophilinduced SC production. (a) Calu-3 cells were incubated (or not, as control) for $48 \mathrm{hrs}$ with TFG- $\beta 1(20 \mathrm{ng} / \mathrm{ml})$ or neutrophils $(5 \times$ $10^{6}$ cells) in the presence or not of the antioxidants $\mathrm{N}$-acetylcysteine (NAC,10 mM, grey bars) or glutathione (GSH, $10 \mathrm{mM}$, solid bars). Supernatants were assayed for SC by ELISA. Data are means \pm SEM $(n=3) .{ }^{*} P<.05$ as compared with control. (b) Calu-3 cells were cocultured (in a 24 -wells plate) with neutrophils $\left(80 \times 10^{6}\right.$ cells) in the presence or not of NAC (10 mM) for 5 to $120 \mathrm{~min}$, and phosphorylation of ERK1/2 and p38 was assayed by western blot, as compared to $\beta$-actin as loading control.

a dose-dependent increase in SC expression was observed upon exogenous TGF- $\beta$ stimulation. TGF- $\beta$ produced in cocultures ranged from $\sim 0.5$ to $1 \mathrm{ng} / \mathrm{ml}$ (Figure 3 ), a concentration close to levels effectively upregulating SC production (Figure 4(b)). In addition, maximal SC production was reached at $48 \mathrm{hrs}$ of stimulation, both for TGF- $\beta$ and neutrophils. Moreover, functional experiments pointed to common molecular pathways (redox system, p38 MAPK), further supporting that neutrophils could induce pIgR/SC expression mainly by producing TGF- $\beta$.

While elastase is the major serine proteinase released by neutrophils involved in lung tissue breakdown due to
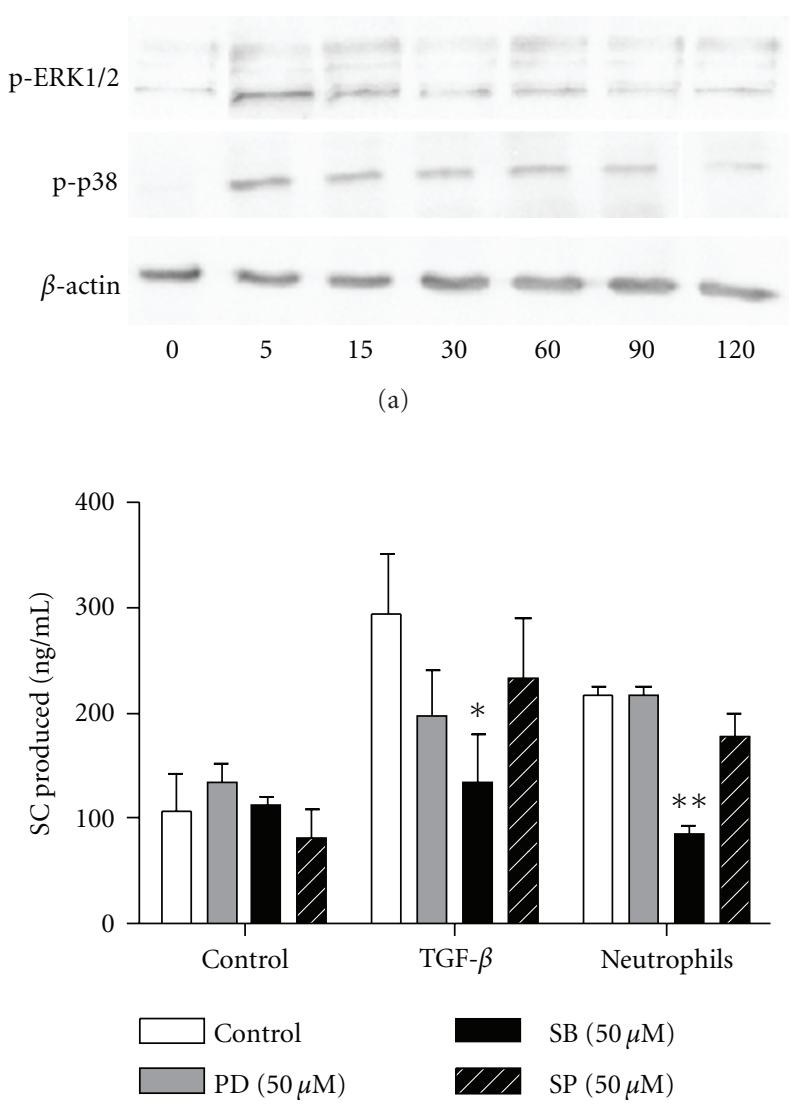

(b)

FIGURE 6: Effect of MAP kinase inhibitors on pIgR/SC production. (a) Calu-3 cells were cultured with TGF- $\beta 1(20 \mathrm{ng} / \mathrm{ml})$ for 5 to $120 \mathrm{~min}$ and phosphorylation of ERK1/2 and p38 was assayed by western blot, as compared to $\beta$-actin as loading control. (b) Calu3 cells were cultured with TGF- $\beta 1(20 \mathrm{ng} / \mathrm{ml})$ or neutrophils $(5 \times$ $10^{6}$ cells) for $48 \mathrm{hrs}$ in the presence of medium alone (control) or MAP Kinase inhibitors: PD98059 (grey bars), SB203580 (solid bars) or SP600125 (stripped bars) (all $50 \mu \mathrm{M}$ ) as selective inhibitors of ERK1/2 MAPK, p38 MAPK and JNK MAPK, respectively. SC production was assessed in supernatants and results were shown as means \pm SEM $(n=4) .{ }^{*} P<.05,{ }^{* *} P<.01$ as compared with control.

cigarette smoking (know as "emphysema"), TGF- $\beta$ represents a multifunctional growth factor. It modulates cell proliferation and differentiation and induces synthesis of extracellular matrix proteins $[10,11]$ and is thereby involved in the development of tissue fibrosis. TGF- $\beta$ has also been shown as chemotactic for neutrophils, while exerting prominent immunosuppressive functions [12]. In addition, it has a unique role in mucosal tissues in promoting class switch recombination of mucosal plasma cells to IgA, a critical Ig for prevention of microbial infection and for control of the commensal flora $[13,14]$. Here, we show that TGF- $\beta$ not only triggers IgA synthesis but also promotes its transport across the epithelium, further supporting the view of this cytokine as a critical factor in mucosal homeostasis. Bronchial epithelial cells can also produce TGF- $\beta$ either constitutively or upon stimulation such as by cigarette 
smoke $[15,16]$, whereas IFN- $\gamma$ inhibits epithelial TGF- $\beta$ release whilst promoting $\mathrm{pIgR} / \mathrm{SC}$ expression. Intriguingly, it was shown that TGF- $\beta$ expression is increased in small airway epithelium from smokers and patients with COPD $[17,18]$, and was suggested as a factor downregulating SLPI expression in these patients [19]. A reduction in SLPI secretion can also be induced by elastase, as recently reported [20]. Of note, no production of SLPI (or elafin) was detected in our study using Calu-3 cells (data not shown). Thus, it remains to investigate whether relationships between TGF- $\beta$ signalling and epithelial functionsincluding production of $\mathrm{pIgR} / \mathrm{SC}$ and SLPI-are affected in COPD.

In healthy subjects, a balance between oxidants and antioxidants keeps the extracellular environment in a reduced state. Cigarette smoke, which contains massive amounts of oxidants, is the most important risk factor for the development of COPD [21]. The major nonenzymatic antioxidant of the lung is glutathione (GSH) [22]. Our results showed that glutathione or $\mathrm{N}$-acetylcysteine, a glutathione precursor, inhibited the epithelial SC production induced by TGF- $\beta$ or by neutrophils. TGF- $\beta$ is produced in an inactive form, complexed to the latency-associated peptide (LAP), and this complex needs to be dissociated to release active TGF- $\beta$. Reactive oxygen species (ROS) are able to oxidize LAP and to release active TGF- $\beta$, this effect being prevented by oxidant scavenging [16]. The main cellular sources of ROS in the lung not only include activated phagocytes such as neutrophils but also structural cells such as endothelial cells, alveolar and bronchial epithelial cells $[23,24]$. Accordingly, it is plausible that in our study GSH and NAC prevented TGF- $\beta$ activation by neutrophil (or epithelial cell)—derived oxidants, thereby inhibiting TGF- $\beta$-induced SC production. In addition, antioxidants could also affect epithelial intracellular signalling, including p38 MAPK activation $[25,26]$. Similarly, the natural antiproteinase SLPI might modulate TGF- $\beta$ - and neutrophildriven epithelial cell activation, such as $\mathrm{NF} \kappa \mathrm{B}$ pathway [27]. However, our data support that SLPI further promotes SC upregulation upon neutrophil coculture not by affecting epithelial cell signalling but rather by inhibiting elastase activity.

Intracellular kinases play a crucial role in the control of activation of (anti)inflammatory genes in the airways, in T-cell function and tissue remodelling. In particular, MAP kinases control in airway epithelial cells the transcription of several genes involved in COPD pathogenesis such as mucins and inflammatory mediators (e.g., TNF- $\alpha$, IL-8, and matrix metalloproteinases) [28]. Neutrophil- and TGF$\beta$-driven SC upregulation in epithelial cells was almost completely abolished by the inhibitor SB203580, indicating the requirement for p38 MAPK activation, in contrast to ERK and JNK pathways. In human bronchial epithelial cells, exposure to oxidants (peroxide) activates MAPK cascades, particularly stress responsive p38 MAPK [25, our data]. Thus, oxidative stress, caused by inflammatory cells and/or by cigarette smoke derivatives may upregulate epithelial pIgR/SC production by activating p38 MAPK. Increased numbers of $\mathrm{p} 38$ positive cells were previously observed in alveolar walls of patients with COPD, as compared to smokers and nonsmoking controls [29]. Moreover, p38 inhibitors are effective in several animal models of inflammatory disorders, including COPD [30]. For instance, the inhibitor SB2439063 reduced neutrophilia and expression of inflammatory mediators in a rat model of COPD [31]. However, it has been observed that cytokine-induced synthesis of elafin, another natural epithelial-derived neutrophil elastase inhibitor, is also dependent on p38 MAPK $[32,33]$. Thus, activation of p38 MAPK pathway might be critical in the airways to both inflammatory responses and transactivation of protective epithelial genes, including local anti-proteinases and $\mathrm{pIgR} / \mathrm{SC}$.

In conclusion, this paper demonstrates that activated neutrophils trigger increased epithelial $\mathrm{pIgR} / \mathrm{SC}$ expression through redox- and p38 MAPK-dependent mechanisms. It also highlights a novel mucosal function for TGF- $\beta$, upregulating not only IgA synthesis but also its receptormediated transepithelial transport, and further suggests that the redox balance plays an important role in modulating epithelial responses to neutrophils. Thus, this paper provides a molecular basis for the dual effect of neutrophils on mucosal/secretory immunity which consists of on the one hand on proteolytic cleavage of pIgR/SC (and IgA) by elastase and proteinase-3 [8], and on the other hand on TGF- $\beta$-mediated activation of $\mathrm{pIgR/SC}$ synthesis via oxidant- and p38-dependent pathways. These findings are relevant to airway cell biology and neutrophilic airway diseases, suggesting that imbalance between the two identified opposite regulatory mechanisms of $\mathrm{pIgR} / \mathrm{SC}$ may lead to downregulation of secretory IgA immunity, as observed in smokers who developed severe COPD [6]. The cellular and molecular determinants of this (im)balance and fine tuning of pIgR expression will be further investigated in primary cultures of airway epithelial cells from COPD patients.

\section{Acknowledgments}

This paper was part of a grant from the Fonds National de la Recherche Scientifique (FNRS Belgium, grant F.R.S.M. 3.4582.08). C. Ratajczak is a recipient of a Grant from the Fonds Spéciaux de la Recherche (FSR 2008), Université catholique de Louvain (UCL) and C. Pilette is a recipient of a clinicien-chercheur fellowship from the FNRS.

\section{References}

[1] C. Pilette, S. R. Durham, J. P. Vaerman, and Y. Sibille, "Mucosal immunity in asthma and chronic obstructive pulmonary disease: a role for immunoglobulin A?" Proceedings of the American Thoracic Society, vol. 1, no. 2, pp. 125-135, 2004.

[2] P. Brandtzaeg, "Role of secretory antibodies in the defence against infections," International Journal of Medical Microbiology, vol. 293, no. 1, pp. 3-15, 2003.

[3] C. S. Kaetzel, "The polymeric immunoglobulin receptor: bridging innate and adaptive immune responses at mucosal surfaces," Immunological Reviews, vol. 206, pp. 83-99, 2005. 
[4] D. M. Mannino and A. S. Buist, "Global burden of COPD: risk factors, prevalence, and future trends," Lancet, vol. 370, no. 9589, pp. 765-773, 2007.

[5] J. L. Curtis, C. M. Freeman, and J. C. Hogg, "The immunopathogenesis of chronic obstructive pulmonary disease: insights from recent research," Proceedings of the American Thoracic Society, vol. 4, no. 7, pp. 512-521, 2007.

[6] C. Pilette, B. Colinet, R. Kiss et al., "Increased galectin-3 expression and intra-epithelial neutrophils in small airways in severe COPD," European Respiratory Journal, vol. 29, no. 5, pp. 914-922, 2007.

[7] C. Pilette, V. Godding, R. Kiss et al., "Reduced epithelial expression of secretory component in small airways correlates with airflow obstruction in chronic obstructive pulmonary disease," American Journal of Respiratory and Critical Care Medicine, vol. 163, no. 1, pp. 185-194, 2001.

[8] C. Pilette, Y. Ouadrhiri, F. Dimanche, J.-P. Vaerman, and Y. Sibille, "Secretory component is cleaved by neutrophil serine proteinases but its epithelial production is increased by neutrophils through NF- $\kappa \mathrm{B}$ - and p38 mitogen-activated protein kinase-dependent mechanisms," American Journal of Respiratory Cell and Molecular Biology, vol. 28, no. 4, pp. 485498, 2003.

[9] R. Bruggisser, K. Von Daeniken, G. Jundt, W. Schaffner, and H. Tullberg-Reinert, "Interference of plant extracts, phytoestrogens and antioxidants with the MTT tetrazolium assay," Planta Medica, vol. 68, no. 5, pp. 445-448, 2002.

[10] V. M. Keatings and P. J. Barnes, "Granulocyte activation markers in induced sputum: comparison between chronic obstructive pulmonary disease, asthma, and normal subjects," American Journal of Respiratory and Critical Care Medicine, vol. 155, no. 2, pp. 449-453, 1997.

[11] G. R. Grotendorst, G. Smale, and D. Pencev, "Production of transforming growth factor beta by human peripheral blood monocytes and neutrophils," Journal of Cellular Physiology, vol. 140, no. 2, pp. 396-402, 1989.

[12] R. A. Fava, N. J. Olsen, A. E. Postlethwaite et al., "Transforming growth factor $\beta 1$ (TGF- $\beta 1$ ) induced neutrophil recruitment to synovial tissues: implications for TGF- $\beta$ driven synovial inflammation and hyperplasia," Journal of Experimental Medicine, vol. 173, no. 5, pp. 1121-1132, 1991.

[13] P. van Vlasselaer, J. Punnonen, and J. E. De Vries, "Transforming growth factor- $\beta$ directs IgA switching in human B cells," Journal of Immunology, vol. 148, no. 7, pp. 2062-2067, 1992.

[14] T. M. McIntyre, M. R. Kehry, and C. M. Snapper, "Novel in vitro model for high-rate IgA class switching," Journal of Immunology, vol. 154, no. 7, pp. 3156-3161, 1995.

[15] O. Sacco, D. Romberger, A. Rizzino, J. D. Beckmann, S. I. Rennard, and J. R. Spurzem, "Spontaneous production of transforming growth factor- $\beta 2$ by primary cultures of bronchial epithelial cells. Effects on cell behavior in vitro," Journal of Clinical Investigation, vol. 90, no. 4, pp. 1379-1385, 1992.

[16] R. D. Wang, J. L. Wright, and A. Churg, "Transforming growth factor- $\beta 1$ drives airway remodeling in cigarette smokeexposed tracheal explants," American Journal of Respiratory Cell and Molecular Biology, vol. 33, no. 4, pp. 387-393, 2005.

[17] W. I. de Boer, A. van Schadewijk, J. K. Sont et al., "Transforming growth factor $\beta 1$ and recruitment of macrophages and mast cells in airways in chronic obstructive pulmonary disease," American Journal of Respiratory and Critical Care Medicine, vol. 158, no. 6, pp. 1951-1957, 1998.
[18] H. Takizawa, M. Tanaka, K. Takami et al., "Increased expression of transforming growth factor- $\beta 1$ in small airway epithelium from tobacco smokers and patients with chronic obstructive pulmonary disease (COPD)," American Journal of Respiratory and Critical Care Medicine, vol. 163, no. 6, pp. 1476-1483, 2001.

[19] B.-L. Luo, R.-C. Niu, J.-T. Feng, C.-P. Hu, X.-Y. Xie, and L.-J. Ma, "Downregulation of secretory leukocyte proteinase inhibitor in chronic obstructive lung disease: the role of TGF$\beta /$ Smads signaling pathways," Archives of Medical Research, vol. 39, no. 4, pp. 388-396, 2008.

[20] A. L. Sullivan, T. Dafforn, P. S. Hiemstra, and R. A. Stockley, "Neutrophil elastase reduces secretion of secretory leukoproteinase inhibitor (SLPI) by lung epithelial cells: role of charge of the proteinase-inhibitor complex," Respiratory research, vol. 9, p. 60, 2008.

[21] J. M. Sethi and C. L. Rochester, "Smoking and chronic obstructive pulmonary disease," Clinics in Chest Medicine, vol. 21, no. 1, pp. 67-86, 2000.

[22] I. Rahman and I. M. Adcock, "Oxidative stress and redox regulation of lung inflammation in COPD," European Respiratory Journal, vol. 28, no. 1, pp. 219-242, 2006.

[23] V. L. Kinnula, L. Chang, J. I. Everitt, and J. D. Crapo, "Oxidants and antioxidants in alveolar epithelial type II cells: In situ, freshly isolated, and cultured cells," American Journal of Physiology - Lung Cellular and Molecular Physiology, vol. 262, no. 1, pp. L69-L77, 1992.

[24] V. L. Kinnula, L. Y. Chang, Y. S. Ho, and J. D. Crapo, "Hydrogen peroxide release from alveolar macrophages and alveolar type II cells during adaptation to hyperoxia in vivo," Experimental Lung Research, vol. 18, no. 5, pp. 655-673, 1992.

[25] I. Jaspers, J. M. Samet, S. Erzurum, and W. Reed, "Vanadiuminduced $\kappa \mathrm{B}$-dependent transcription depends upon peroxideinduced activation of the p38 mitogen-activated protein kinase," American Journal of Respiratory Cell and Molecular Biology, vol. 23, no. 1, pp. 95-102, 2000.

[26] Y. Q. Xiao, C. G. Freire-de-Lima, W. J. Janssen et al., "Oxidants selectively reverse TGF- $\beta$ suppression of proinflammatory mediator production," Journal of Immunology, vol. 176, no. 2, pp. 1209-1217, 2006.

[27] C. C. Taggart, S.-A. Cryan, S. Weldon et al., "Secretory leucoprotease inhibitor binds to NF- $\kappa \mathrm{B}$ binding sites in monocytes and inhibits p65 binding," Journal of Experimental Medicine, vol. 202, no. 12, pp. 1659-1668, 2005.

[28] I. M. Adcock and G. Caramori, "Kinase targets and inhibitors for the treatment of airway inflammatory diseases: the next generation of drugs for severe asthma and COPD?" BioDrugs, vol. 18, no. 3, pp. 167-180, 2004.

[29] T. Renda, S. Baraldo, G. Pelaia et al., "Increased activation of p38 MAPK in COPD," European Respiratory Journal, vol. 31, no. 1, pp. 62-69, 2008.

[30] P. J. Barnes, "Novel signal transduction modulators for the treatment of airway diseases," Pharmacology and Therapeutics, vol. 109, no. 1-2, pp. 238-245, 2006.

[31] D. C. Underwood, R. R. Osborn, S. Bochnowicz et al., "SB 239063, a p38 MAPK inhibitor, reduces neutrophilia, inflammatory cytokines, MMP-9, and fibrosis in lung," American Journal of Physiology, vol. 279, no. 5, pp. L895-L902, 2000.

[32] J.-M. Sallenave, "The role of secretory leukocyte proteinase inhibitor and elafin (elastase-specific inhibitor/skin-derived 
antileukoprotease) as alarm antiproteinases in inflammatory lung disease," Respiratory Research, vol. 1, no. 2, pp. 87-92, 2000.

[33] R. Pfundt, M. Wingens, M. Bergers, M. Zweers, M. Frenken, and J. Schalkwijk, "TNF- $\alpha$ and serum induce SKALP/elafin gene expression in human keratinocytes by a p38 MAP kinasedependent pathway," Archives of Dermatological Research, vol. 292 , no. 4, pp. 180-187, 2000. 

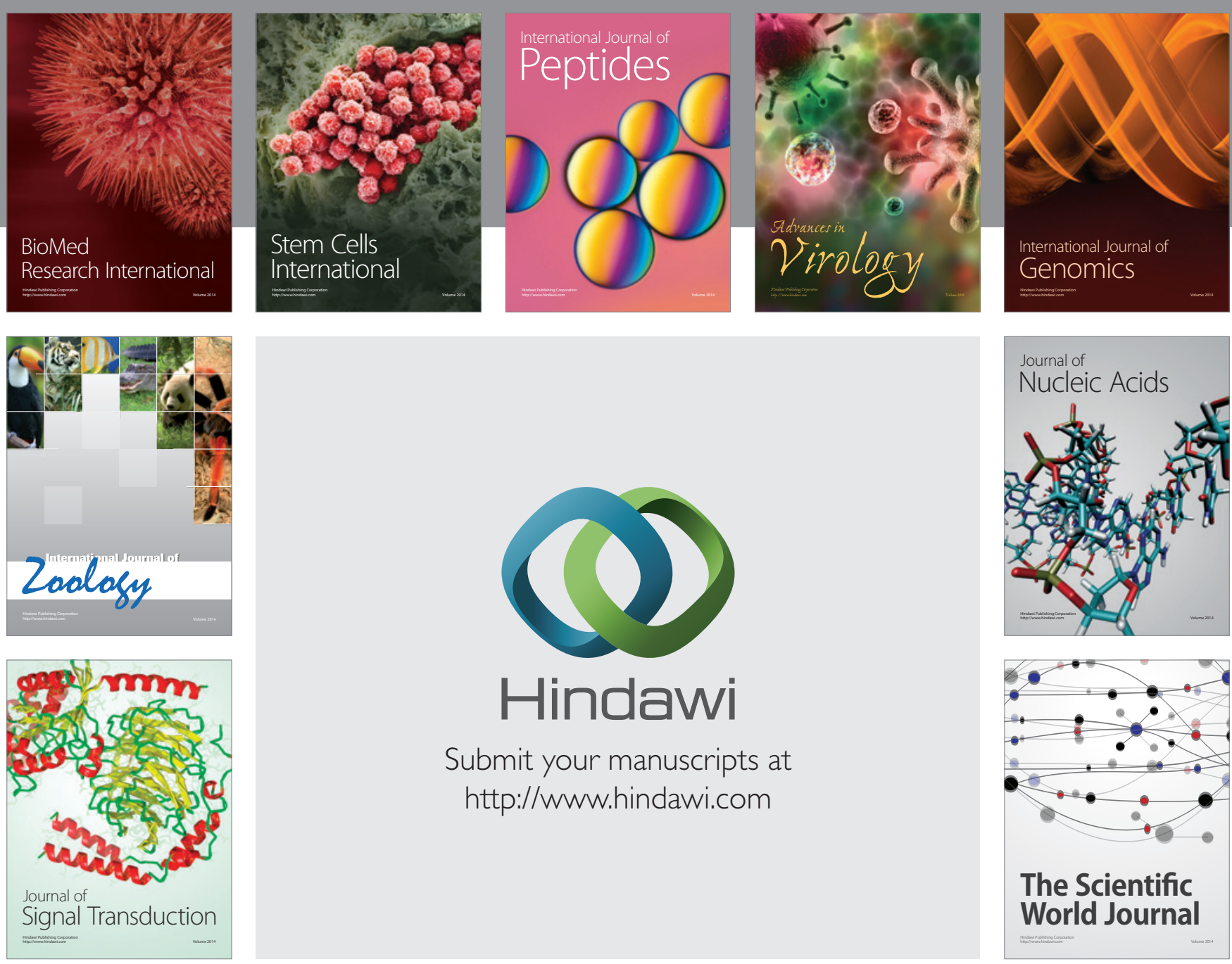

Submit your manuscripts at

http://www.hindawi.com
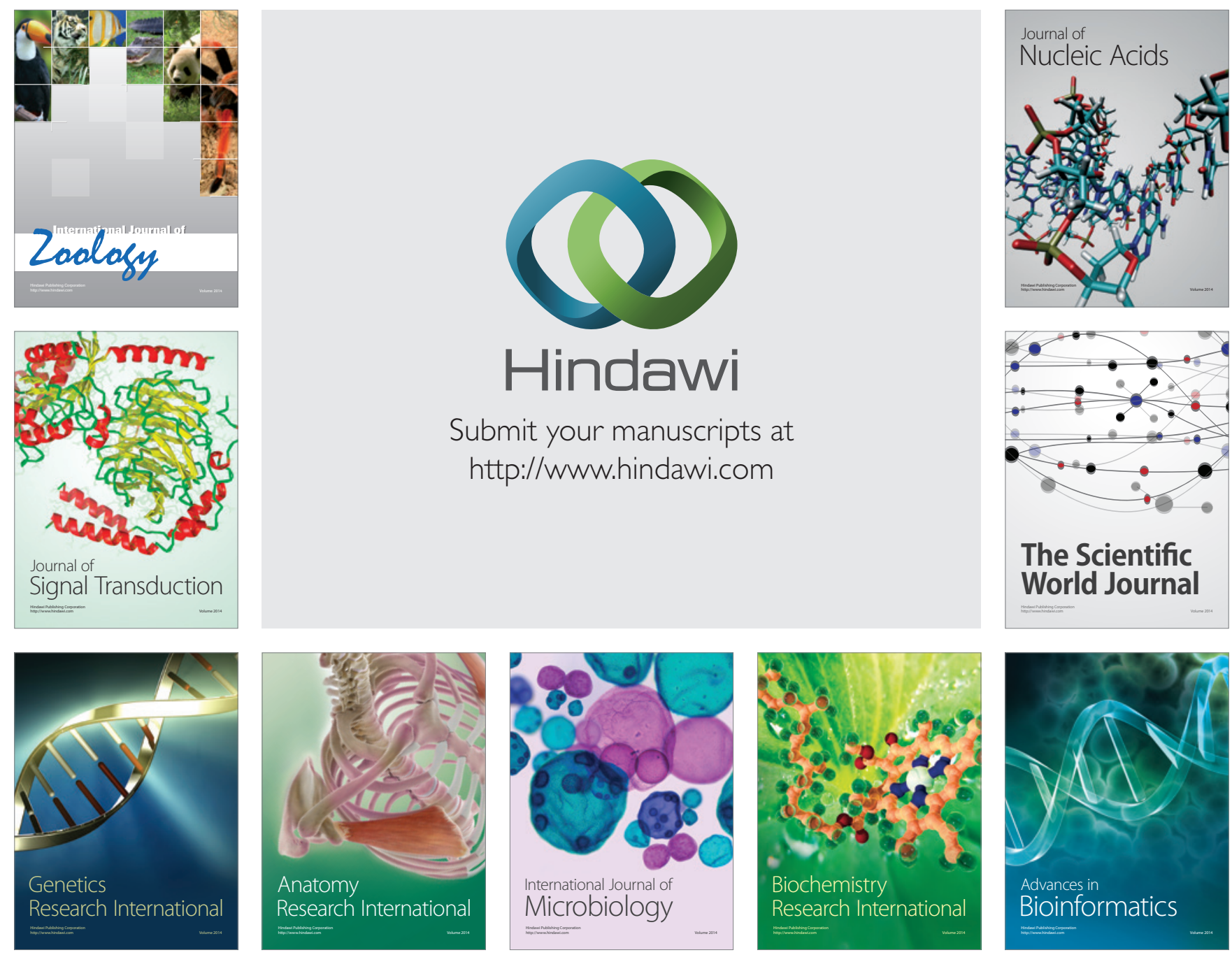

The Scientific World Journal
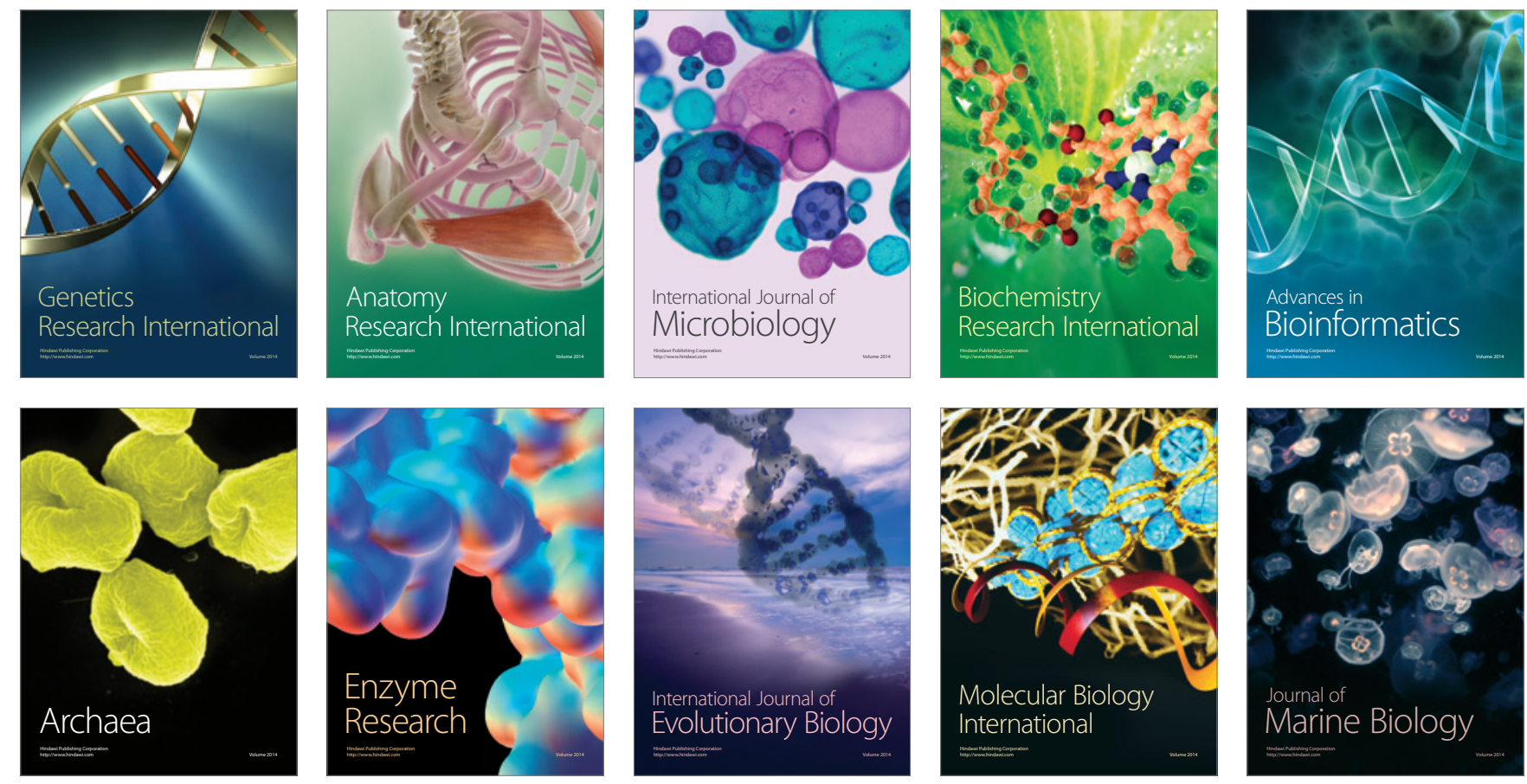